\title{
DID JANUARY 25TH EGYPTIAN REVOLUTION CHANGE THE MEDICO-LEGAL PATTERN AND THE TREND OF HOSPITALIZED INJURIES IN UPPER EGYPT? A RETROSPECTIVE STUDY.
}

\author{
Doaa M. El Shehaby ${ }^{1}$, Medhat A. Saleh ${ }^{2}$, Mohammed S. Shahine ${ }^{3}$, Mostafa M. Sayed ${ }^{4}$ \\ ${ }^{1}$ Department of Forensic Medicine and Clinical Toxicology, ${ }^{2}$ Department of Public Health \\ and Community Medicine, ${ }^{3}$ Maxillo-facial Surgery unit, ${ }^{4}$ General Surgery Department: \\ Faculty of Medicine, Assiut University, Egypt
}

\begin{abstract}
Background and Rationale: Trauma is a wound or injury caused by mechanical or physical factors. Trauma is a medical case with legal implications. Revolution of Egypt in the 25th of January 2011 was accompanied by dramatic changes in the Egyptian community attitudes that certainly had legal implications. Aim of the study: was to assess the changes in the medico-legal pattern of hospitalized trauma cases with evaluation of the homicidal cases concerning the cause and the final outcome especially in the post-revolution period. Participants and Methods: This study was a retrospective one that included 1527 hospitalized trauma cases who were collected from Trauma Unit of Assiut University Hospital in the period between January 2010 and December 2016. All the needed data was collected from health information system database of the Trauma Unit after taking the official consent from the unit director. The collected data included basic demographic data, cause of injury, mechanisms, mode and outcomes of trauma in all hospitalized cases. Results: 1527 hospitalized trauma cases were collected; mean age was $25.39 \pm 15.4$ years, male: female ratio was (6.6:1). The annual number of trauma cases was almost equal in the first 5 years then decreased gradually after that. Homicidal mode (assault from others) was approximately doubled from $22.6 \%$ in 2010 (before revolution) to $40.5 \%$ in 2011 and $38.0 \%$ in 2012 (after revolution), then decreased gradually in 2014 till 2016, also firearm injuries increased from $9.6 \%$ before revolution (2010) to $14.3 \%$ in 2011 and jumped to $31.0 \%$ in 2012 and $37.3 \%$ in 2013 then, decreased gradually after that. The accidental mode road traffic accident decreased from $40 \%$ before revolution to $26 \%$ and 20\% in 2011 and 2012 respectively (after revolution). Conclusions: January 25th Egyptian revolution clearly changed the medico-legal pattern of trauma; from accidental pattern (road traffic accidents \& falls) before revolution to homicidal pattern (assault from others \& firearm injuries) in the post revolution period.
\end{abstract}

Keywords: Trauma; Medico-Legal pattern, 25th Revolution, Assiut, Egypt.

\section{INTRODUCTION}

Injuries represent a major preventable, epidemic, noncommunicable and growing public health worldwide problem in the present century (Murray and Lopez, 1997). Violence affects a significant proportion of the population. It threatens the lives as well as physical and mental health of millions of people, overburdens healthcare systems, undermines human capital formation, and slows economic and social development (Aldinger et al., 2011). It is the leading cause of mortality and 
disability during the first four decades of life (Mann and Russell, 1991).

Clinically a wound is produced when there is a breach in the anatomical continuity of the skin or mucous membrane with or without damage of the underlying tissues. Law enforcing officers may send the wounded victims for routine treatment and necessarily for medico-legal reports. Occasionally the victims from their own selves request the attending physician to issue medical reports which will be needed to start a legal action against the accused persons (Barek and Haque, 2013). Attending physicians have a duty to evaluate cases of medico-legal trauma and to transmit judicial findings to the appropriate judicial authorities in accordance with accepted procedures (Korkmaz et al., 2012). In reporting trauma cases, the clinical state of the victim with full description of the wounds are noted and an opinion regarding their legal state i.e. whether serious or simple, age of the injury, type of the weapon that causing the injury all these help the court to give its judgment ((Mant, 1984 and Saadat et al., 2011).

Trauma presents with a variety of injuries and problems that demand rapid evaluation, discussion and intervention to save the life and prevent permanent disability. Injuries are classified as intentional or unintentional. Unintentional injury includes injuries related to traffic, falls and drowning. Intentional injury includes interpersonal violence and homicide (Tabish et al., 2004). The Egyptian revolution carries a challenging transition phase, starting out with problems such as low foreign direct investments (FDI), a high budget deficit, a high debt rate, a high unemployment rate, a high poverty rate, and a low standard of living (Abdou and Zaazou, 2013). During the revolution, the level of security in general and the efficiency of the security system have decreased in urban as well as rural areas; 4000 police vehicles were destroyed, thereby affecting mobile security capacity. Several segments of society have control over weapons which were confiscated from police stations, and smuggled through tunnels from Gaza, or through the boarders from Libya. Car thefts, thugs' criminal actions, and the looting of antiquities have increased immensely (Ottaway, 2011).

\section{AIM OF THE WORK}

The study aimed to assess the pattern of trauma in the admitted and hospitalized cases to the Trauma Unit to study these trauma cases regarding types and mechanisms with special emphasis of the post-revolution period.

\section{RESEARCH METHODOLOGY}

The study is a retrospective study conducted in the trauma unit of Assiut University Hospital, Assiut, Egypt. Trauma Unit of Assiut University Hospital of Upper Egypt is considered as the central unit of trauma in Upper Egypt, to which injury cases are referred from all Upper Egypt and Red Sea Governorates. Assiut University Trauma Unit is a tertiary unit which receives all referred trauma cases that need special care from all medical facilities in Upper Egypt. Data of the admitted injury cases during the period between the start of January 2010 and the end of December 2016) were obtained from the database office at the Trauma Unit of Assiut University Hospitals. Data registration was done by the residents at the Trauma Unit and data entry was performed by well trained personnel. 
The collected data included basic demographic data (age, sex, residence, occupation), duration of admission, mechanism of trauma (Firearm injury, motor car accident, assault from others, falls, animal bite), mode of the injury (accidental, homicidal or suicidal) and the outcome of injury (death, improvement, escape before intervention or discharge on demand).

\section{Ethical consideration:}

Official consent from director of the Trauma Unit of Assiut University Hospital was obtained to take all needed data from the electronic health information system database. The obtained data were confidential and for the purpose of the scientific research only. The study protocol was approved by the ethical committee, Faculty of Medicine, Assiut University, Egypt.

\section{Statistical analysis:}

Data were tabulated in an Excel sheet (Microsoft office 2010), then were analyzed using advanced statistical package for social sciences (SPSS version 22) (SPSS, Inc., Chicago, IL). The results were expressed as frequency and percent in qualitative data and mean \pm SD for quantitative data. Chi- square test was used for comparison of qualitative data, $\mathrm{p}$ values less than 0.05 were considered statistically significant.

\section{RESULTS}

Table (1) showed that the total number of patients admitted to the Trauma Unit in the 7 years period was 1527 patients; $86.5 \%$ males and $13.5 \%$ females, with male to female ratio (6.6: $1)$. The annual number of trauma patients was almost equal in the first 5 years ranged from 14 to $17 \%$ but this number reduced to $11.9 \%$ in 2015 then reduced to $9 \%$ in 2016 . The age of the admitted patients ranged from one year up to 88 years with mean age of 25.39 \pm 15.4 years. The table also showed that students and workers represented up to $50 \%$ of the patients $(26.3 \%$ and $23.1 \%$ respectively) followed by no work $17 \%$ and farmer $13.6 \%$. More than three quarters of the patients were from Assiut governorate and about one quarter $(24.5 \%)$ were from outside Assiut.

Table (1): Demographic data of hospitalized injured cases in the studied period (20102016)

\begin{tabular}{|c|c|}
\hline Variable & Cases $=1527$ No. $(\%)$ \\
\hline $\begin{array}{ll}\text { Year } & \\
\text { - } & 2010 \text { (before revolution) } \\
\text { - } & 2011 \text { (after revolution) } \\
\text { - } & 2012 \\
\text { - } & 2013 \\
\text { - } & 2014 \\
\text { - } & 2015 \\
\text { - } & 2016\end{array}$ & $\begin{array}{lll}\text { - } & 270 & (17.7) \\
- & 237 & (15.5) \\
\text { - } & 245 & (16.0) \\
\text { - } & 236 & (15.5) \\
\text { - } & 220 & (14.4) \\
- & 181 & (11.9) \\
\text { - } & 138 & (9.0) \\
\end{array}$ \\
\hline $\begin{array}{ll}\text { Sex } & \\
\bullet & \text { Male } \\
- & \text { Female } \\
\end{array}$ & $\begin{array}{ll}\bullet & 1321(86.5) \\
\bullet & 206(13.5) \\
\end{array}$ \\
\hline $\begin{array}{l}\text { Age: mean } \pm \text { SD (range) } \\
\text { Duration of admission: mean } \pm \mathrm{SD} \text { (range) }\end{array}$ & $\begin{array}{ll} & 25.39 \pm 15.4(1: 88) \\
\text { - } & 8.2 \pm 8.8(1: 120)\end{array}$ \\
\hline
\end{tabular}




\begin{tabular}{|ll|ll|}
\hline \multicolumn{2}{l|}{ Occupation of the cases } & $\bullet$ & $259(17.0)$ \\
$\bullet$ & no work & $\bullet$ & $54(3.5)$ \\
$\bullet$ & child & $\bullet$ & $401(26.3)$ \\
- & student & $\bullet$ & $353(23.1)$ \\
- & worker & $\bullet$ & $144(9.4)$ \\
- & employer & $\bullet$ & $95(6.2)$ \\
- & male child & $\bullet$ & $207(13.6)$ \\
$\bullet$ & farmer & $\bullet$ & $11(0.7)$ \\
$\bullet$ & retirement & $\bullet$ & $3(0.3)$ \\
\hline & prisoner & \\
\hline
\end{tabular}

Fig (1) showed that assault from others took the upper hand in all mechanisms and represented 29\% followed by road traffic accidents and firearm injuries $(28 \%$ and $26 \%$ respectively), fall from height represents $15 \%$ and finally animal bite $2 \%$.

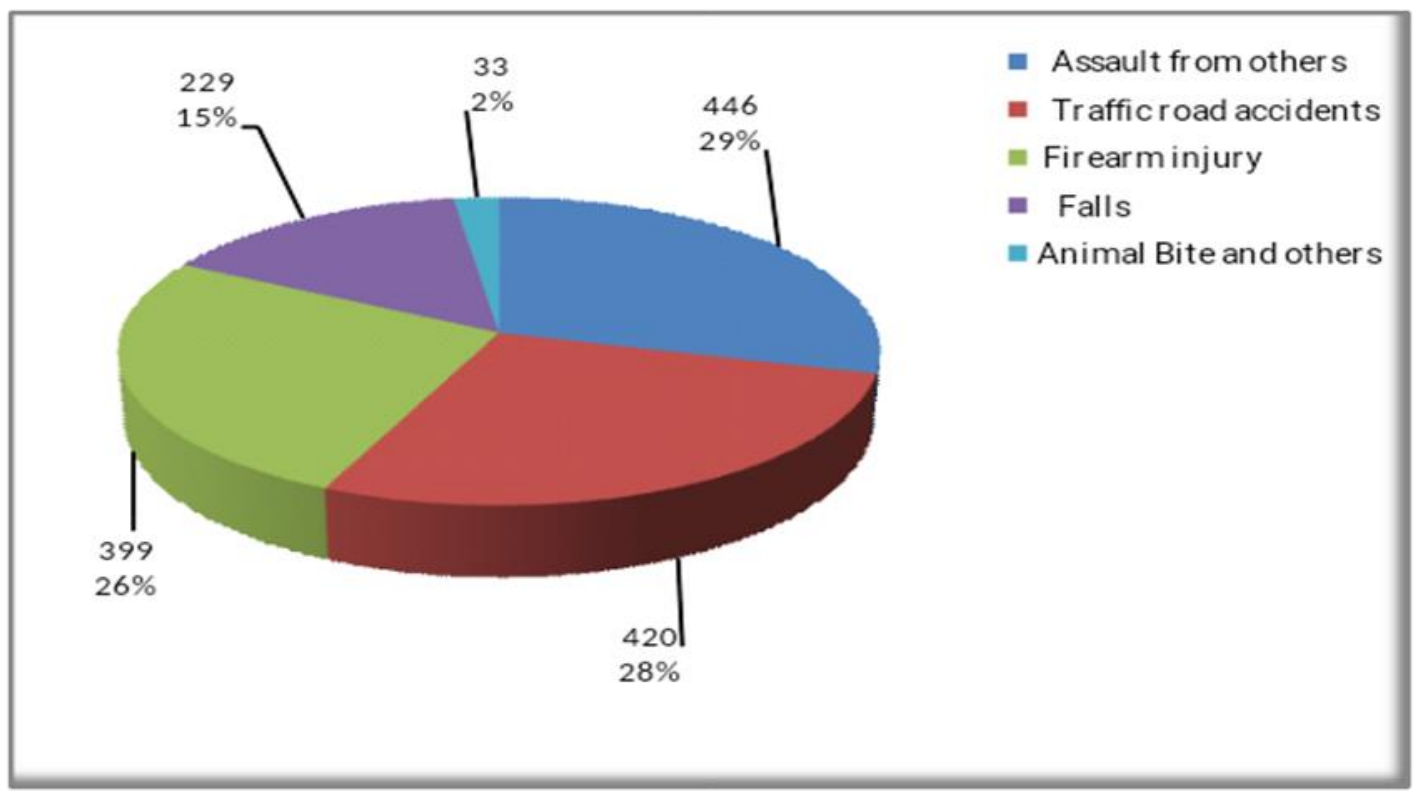

Figure (1): Causes of trauma among hospitalized injured cases in the studied period (2010: 2016).

Fig (2) showed final outcome of admitted trauma cases irrespective of its cause and revealed that $77.3 \%$ of the admitted cases improved, $15.7 \%$ died,
$5.9 \%$ escaped before intervention, while $1.2 \%$ of patients discharged on demand. 


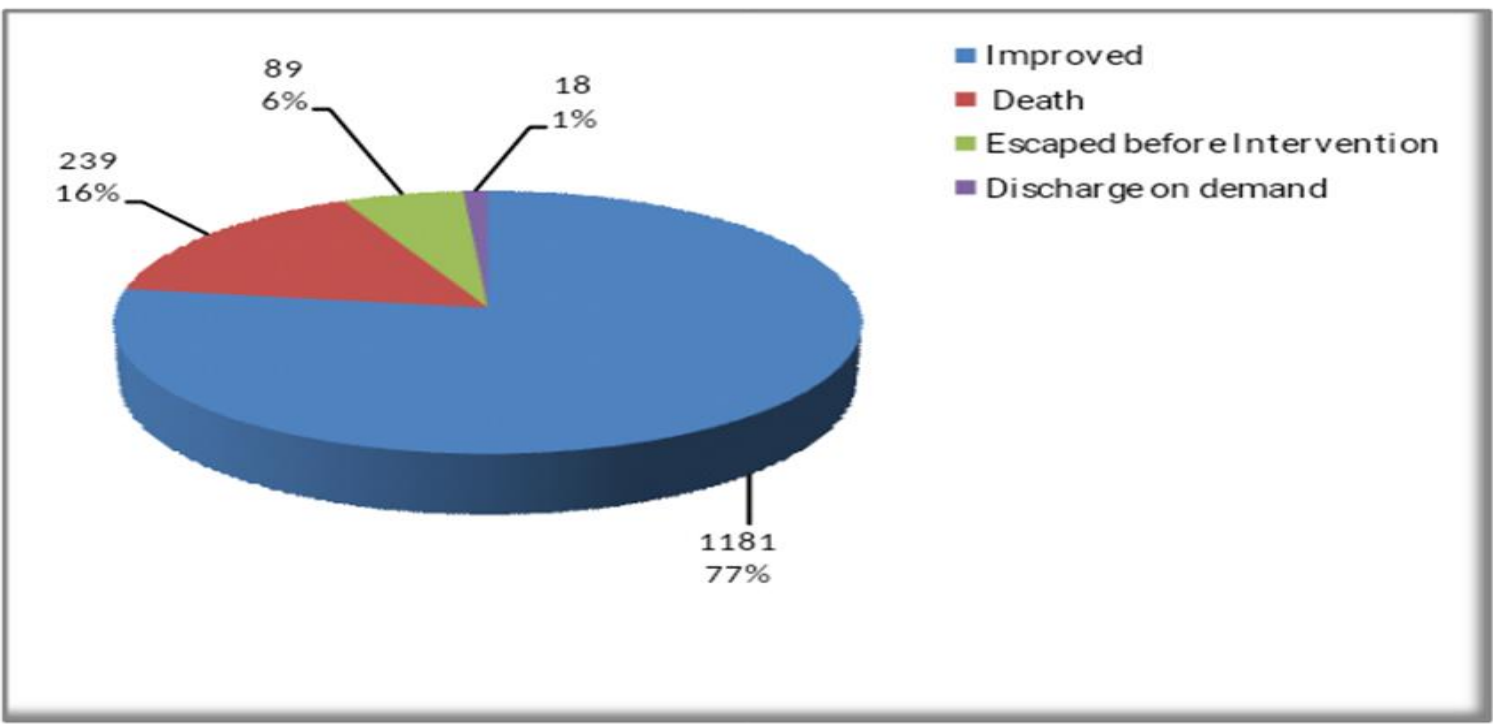

Figure (2): Distribution of different outcomes of trauma in the hospitalized injured cases in the studied period (2010: 2016)

Fig (3) revealed that assault from others approximately doubled from $22.6 \%$ in 2010 (before revolution) to $40.5 \%$ in 2011 and $38.0 \%$ in 2012 (after revolution), also firearm injuries increased from $9.6 \%$ before revolution to $14.3 \%$ in 2011 and jumped to $31.0 \%$ in 2012 and $37.3 \%$ in 2013, while road traffic accident decreased from $40 \%$ before revolution to $26 \%$ and $20 \%$ in 2011 and 2012 respectively (after revolution).

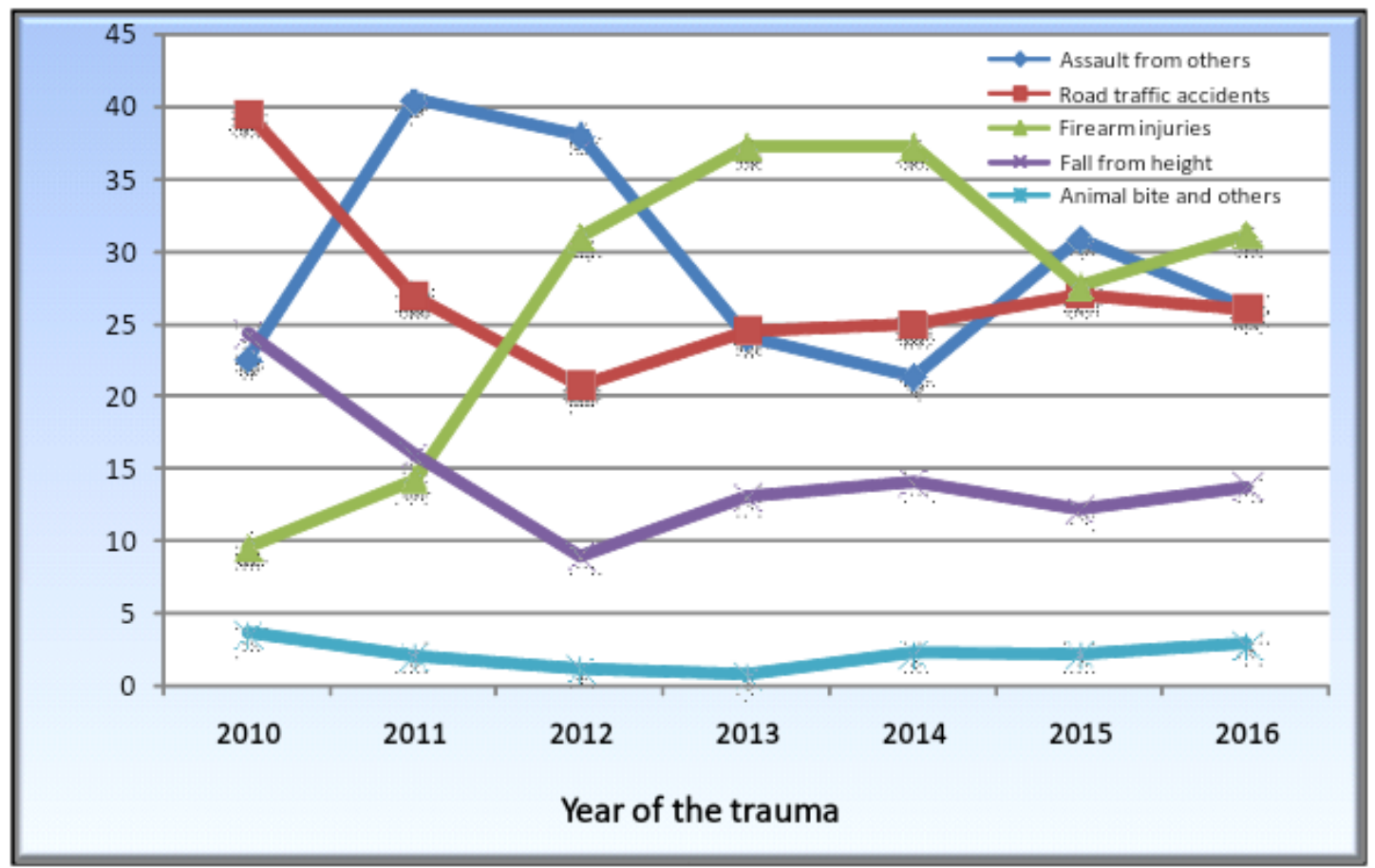

Figure (3): Trend of different causes of trauma among hospitalized injured cases in the studied period (2010: 2016) 
Table (2): showed that there was a statistical significant difference between the different causes of trauma in the hospitalized injured cases in the 7 years study period $(\mathrm{p}=0.0001)$. This difference appeared clearly in assault from others which doubled from $22.6 \%$ in 2010 (before revolution) to $40.5 \%$ in 2011 and $38.0 \%$ in 2012 (after revolution), also firearm injuries increased from $9.6 \%$ (before revolution) to $14.3 \%$ in 2011 and jumped to $31.0 \%$ in 2012 and $37.3 \%$ in 2013(after revolution).

Pairwise comparisons by chi square test was done to detect the difference between each two mechanisms in every year, it revealed statistical significant differences between each pair of all mechanisms in 2010 except between assault from others and animal bites as both have the same superscripts a, also showed a statistical significant differences between each pair of all mechanisms in 2011 except between fall from height and animal bites as both have the same superscripts abc. In 2012, there was statistical significant differences between each pair of all mechanisms except between assault from others and firearm injuries as both have the same superscripts a. In 2013; there was statistical significant differences between firearm injuries and the other 4 mechanisms, in 2014 firearm injuries was statistically significant different from the other mechanisms except animal bites, while in 2015 and 2016 the overall difference was not statistically significant.

Table (2): Distribution of different causes of trauma in the hospitalized injured cases in studied period (2010: 2016)

\begin{tabular}{|c|c|c|c|c|c|c|}
\hline $\begin{array}{c}\text { Year of } \\
\text { the } \\
\text { trauma }\end{array}$ & $\begin{array}{c}\text { Assault } \\
\text { from others } \\
(\mathrm{n}=446)\end{array}$ & $\begin{array}{c}\text { Road traffic } \\
\text { accidents } \\
(\mathrm{n}=420)\end{array}$ & $\begin{array}{c}\text { Firearm } \\
\text { Injuries } \\
(\mathrm{n}=399)\end{array}$ & $\begin{array}{c}\text { Fall } \\
\text { from height } \\
(\mathrm{n}=229)\end{array}$ & $\begin{array}{c}\text { Animal bite } \\
\text { and others } \\
(\mathrm{n}=33)\end{array}$ & $\begin{array}{c}\text { P. value } \\
(\text { Sig.) }\end{array}$ \\
\cline { 2 - 6 } & No. (\%) & No. $(\%)$ & No. $(\%)$ & No. $(\%)$ & No. $(\%)$ & \\
\hline $\mathbf{2 0 1 0}$ & $61(22.6)^{\mathrm{b}}$ & $107(39.6)^{\mathrm{a}}$ & $26(9.6)^{\mathrm{c}}$ & $66(24.4)^{\mathrm{ab}}$ & $10(3.7)^{\mathrm{a}}$ & $<0.0001^{* *}$ \\
\hline $\mathbf{2 0 1 1}$ & $96(40.5)^{\mathrm{a}}$ & $64(27.0)^{\mathrm{b}}$ & $34(14.3)^{\mathrm{c}}$ & $38(16.0)^{\mathrm{abc}}$ & $5(2.1)^{\mathrm{abc}}$ & $<0.0001^{* *}$ \\
\hline $\mathbf{2 0 1 2}$ & $93(38.0)^{\mathrm{a}}$ & $51(20.8)^{\mathrm{b}}$ & $76(31.0)^{\mathrm{a}}$ & $22(9.0)^{\mathrm{c}}$ & $3(1.2)^{\mathrm{ab}}$ & $<0.0001^{* *}$ \\
\hline $\mathbf{2 0 1 3}$ & $57(24.2)^{\mathrm{b}}$ & $58(24.6)^{\mathrm{b}}$ & $88(37.3)^{\mathrm{a}}$ & $31(13.1)^{\mathrm{b}}$ & $2(0.8)^{\mathrm{b}}$ & $0.0006^{* *}$ \\
\hline $\mathbf{2 0 1 4}$ & $47(21.4)^{\mathrm{b}}$ & $55(25.0)^{\mathrm{b}}$ & $82(37.3)^{\mathrm{a}}$ & $31(14.1)^{\mathrm{b}}$ & $5(2.3)^{\mathrm{a}}$ & $0.001^{* *}$ \\
\hline $\mathbf{2 0 1 5}$ & $56(30.9)$ & $49(27.1)$ & $50(27.6)$ & $22(12.2)$ & $4(2.2)$ & $0.82^{\text {NS }}$ \\
\hline $\mathbf{2 0 1 6}$ & $36(26.1)$ & $36(26.1)$ & $43(31.2)$ & $19(13.8)$ & $4(2.9)$ & $0.62^{\text {NS }}$ \\
\hline
\end{tabular}

Chi square test was used in all comparisons

a, b, c Values in the same row with different superscript are significantly different and those with the same superscripts are not significant

** Significant $(\mathbf{p}<0.01)$.

NS: Not significant.

Table (3) showed outcomes of trauma cases in its different causes and revealed that death was more from road traffic accidents (38.1\%) followed by firearm injuries and assault from others (32 and $20.1 \%$ respectively), improvement was more in assault from others (31.6\%) followed by road traffic accidents and firearm injuries (approximately $25 \%$ in both) with statistical significant difference between different outcomes in different causes of trauma $(p=0.0001)$. 
Table (3): Different outcomes among different causes of trauma in hospitalized injured cases

\begin{tabular}{|c|c|c|c|c|c|c|}
\hline \multirow{2}{*}{$\begin{array}{c}\text { Outcome of } \\
\text { cases }\end{array}$} & $\begin{array}{c}\text { Assault } \\
\text { from others }\end{array}$ & $\begin{array}{c}\text { Road traffic } \\
\text { accidents }\end{array}$ & $\begin{array}{c}\text { Firearm } \\
\text { injuries }\end{array}$ & $\begin{array}{c}\text { Fall from } \\
\text { height }\end{array}$ & $\begin{array}{c}\text { Animal bite } \\
\text { and others }\end{array}$ & $\begin{array}{c}\text { P- } \\
\text { Volue }\end{array}$ \\
\hline Improved & $373(31.6)$ & No $(\%)$ & No $(\%)$ & No $(\%)$ & No $(\%)$ & Value \\
\hline Death & $48(20.1)$ & $91(38.1)$ & $78(32.6)$ & $21(8.8)$ & $1(0.4)$ & \\
\hline $\begin{array}{c}\text { Escaped Before } \\
\text { intervention }\end{array}$ & $20(22.5)$ & $29(32.6)$ & $18(20.2)$ & $19(21.3)$ & $3(3.4)$ & 0.0001 \\
\hline $\begin{array}{c}\text { Discharge On } \\
\text { demand }\end{array}$ & $5(27.8)$ & $6(33.3)$ & $4(22.2)$ & $2(11.1)$ & $1(5.6)$ & \\
\hline
\end{tabular}

\section{Chi square test was used}

Table (4) showed that firearm injuries were more common in males $(27.2 \%)$ than female $(19.4 \%)$, Assault from others was also more in males than females $(30.1 \%$ and $23.8 \%$ respectively) while, fall from height was more in females $(25.2 \%)$ than males $(13.4 \%)$ with statistical significant difference between different causes of trauma $(p=0.0001)$.

Table (4): Sex distribution in different causes of trauma among hospitalized injured

cases

\begin{tabular}{|c|c|c|c|c|c|c|}
\hline \multirow{2}{*}{ Sex } & $\begin{array}{c}\text { Assault from } \\
\text { others }\end{array}$ & $\begin{array}{c}\text { Road } \\
\text { traffic } \\
\text { accidents }\end{array}$ & $\begin{array}{c}\text { Firearm } \\
\text { injuries }\end{array}$ & $\begin{array}{c}\text { Fall from } \\
\text { height }\end{array}$ & $\begin{array}{c}\text { Animal } \\
\text { bite and } \\
\text { others }\end{array}$ & \multirow{2}{*}{$\begin{array}{c}\text { P- } \\
\text { Value }\end{array}$} \\
\cline { 2 - 6 } Male & No (\%) & No (\%) & No (\%) & No (\%) & No(\%) & \\
\hline Female & $49(30.1)$ & $362(27.4)$ & $359(27.2)$ & $177(13.4)$ & $26(2.0)$ & \multirow{2}{*}{0.0001} \\
\hline
\end{tabular}

\section{Chi square test was used}

Table (5) showed that more than $55 \%$ of the hospitalized injured cases were homicidal cases including all cases of assault from others and all firearm injured cases except one case.
Accidental mode included road traffic accidents, animal bite, and all cases of falls from height except one case, while suicidal mode was two cases only one firearm and one falls from height.

Table (5): Mode of trauma among hospitalized injured cases in the studied period (2010: 2016)

\begin{tabular}{|c|cl|}
\hline Mode of trauma & \multicolumn{2}{|c|}{ Cases $=1527$} \\
& No. $(\%)$ \\
\hline Homicidal & 844 & $(55.3)$ \\
Accidental & 681 & $(44.6)$ \\
Suicidal & 2 & $(0.1)$ \\
\hline
\end{tabular}

\section{DISCUSSION}


Revolution of Egypt in the 25th of January 2011 was accompanied by dramatic changes in the Egyptian community consequently; these changes played an important role in changing the pattern of trauma regarding its demographic criteria, etiology, mechanism, mode, and final outcome. The years after January 25th revolution were characterized by disturbance in the political safety, lack of general security and escape of prisoners from prison, together with increase in the rate of violence all over the country and increase in the usage of unlicensed weapons in addition to, increase in the armed robbery by 12 times, furthermore killings almost doubled; reached two thousand cases a year which was not more than a thousand cases per year before the revolution (Saad et al., 2016).

The total number of patients admitted to the trauma unit in the 7 years period (2010-2016) was 1527 patients; $86.5 \%$ males and $13.5 \%$ females, with male to female ratio of (6.6: 1) as shown in table (1). This finding was logic as males are more subjected to trauma due to their mobility, moreover males are more likely than females to be involved in violent activities and motor vehicle crashes and often sustain more severe injuries compared to females. Furthermore, when we check the sex pattern of trauma as shown in table 4 , we found that homicidal mode of trauma (firearm injuries and Assaults from others) were more common in males than females although, accidental mode of trauma (falls and road traffic accidents) were more in females than males $(\mathrm{p}=0.0001)$, this finding supported our postulation that we mentioned about male tendency to violence which increased and enriched after January $25^{\text {th }}$ Revolution.

The obtained ratio was much higher than that previously obtained by Mahran et al. (2013) in a similar study; conducted in the same place (Assiut University Trauma Unit) but before revolution in 2009. They reported that male to female ratio was 3: 1 . The mean age of the hospitalized trauma cases was $25.39 \pm 15.4$ years; this indicated that adults were more susceptible to trauma than others. This result provided the evidence that young adults were an important group at risk for injuries, as they are usually very active and mobile and often constitute a great percentage of the economic force. Similar results were obtained in other studies previously conducted by An Egyptian injury surveillance report in 2009 as well as by other studies in South Africa and Nigeria (Bruce et al., 2003),

One of the most important findings in the study is that the total number of hospitalized injured trauma cases in each year was almost the same before and after the $25^{\text {th }}$ January revolution or even reduced after the revolution as shown in table (1), this spotlights our vision to analyze the causes and modes of such trauma in each year seeking for difference in causes and modes before and after revolution which may be attributed to social and political circumstances that accompanied revolution, the same table showed that total number of trauma cases decreased from 270 before revolution to 220 in 2014 and further decreased to 181 in 2015 and markedly decreased to 138 in 2016 (after revolution), this reduction may be attributed to community and political stability after 2014 which accompanied the election of the legal president of Egypt and applying the 
constitution rules after its establishment and election of the parliament members which has great impact on law enforcement. In the same table we found that, students and workers represented up to $50 \%$ of the cases (26.3\% and $23.1 \%$ respectively), which may be related to continuous movement and traveling of both students and workers subjecting them to different causes of trauma especially road traffic and assault from others than other occupations.

The results of the current study pointed to change in the pattern of hospitalized injuries; assault from others ranked as the first type of injury as it occurred in $29 \%$ of cases followed by the road traffic accidents in $28 \%$ of cases (second cause). Firearm injuries ranked as the third cause $(26 \%)$, the falls from height came as the fourth $(15 \%)$ and lastly the animal bite in $2 \%$ of cases.

Assault from others approximately doubled from $22.6 \%$ in 2010 (before revolution) to $40.5 \%$ in 2011 and $38.0 \%$ in 2012 (after revolution) then markedly reduced to $24.2 \%$ and $21.4 \%$ in 2013 and 2014 respectively (table 2 and figure 3 ). This could be explained by the stable political and security circumstances in the year 2010 before the revolution but after the start of revolution events, political conflicts arouse and members of these political groups used violence to express their opinion in political struggles, furthermore fragility and destruction of police forces infrastructures and burning of the police stations with destruction of courts with its official documents together with lawlessness of the whole Egyptian society due to lack of Punishment, all these community and social changes pave the way to aggressive behavior and subsequently increase the frequency of assault from others mode of trauma after revolution. What boosted this assumption was that the frequency of assault from others markedly decreased in 2013 and 2014 when the police forces retained its stability and organizations.

This results mismatched with the result of Mahran et al. (2013 and 2016) study that was conducted in the same region before revolution and aimed to describe the pattern of hospitalized injuries between 2002 to 2009; they concluded that falls were the commonest cause for hospitalized injured cases, followed by transport accidents and then exposure to inanimate mechanical forces which ranked as the third cause. Furthermore, our results were not in agreement with the Egyptian injury surveillance report in 2009 in which falls from height was ranked as the first leading cause of injuries in 2009 (WHO, 2012a).

Within the last two decades, the civilian gunshot injury incidence and their ensuing mortalities have been increased worldwide. Regarding the etiology, firearm injuries are usually a result of assaults or homicides in lower income countries but in high income countries it may be due to suicides. Looking to the frequency of trauma cases before and after revolution, it was found that number of trauma cases were almost equal in the first 5 years ranged from 14 to $17 \%$ but this number decreased to $11.9 \%$ and $9 \%$ in 2015 and 2016 respectively. On the other side, firearm injuries increased from $9.6 \%$ before revolution to $14.3 \%$ in 2011 and jumped to $31.0 \%$ in 2012 and $37.3 \%$ in 2013 respectively $(\mathrm{P}=0.0001)$ as revealed in table 2 and figure 3 . All these numbers are markedly higher than that reported by Mahran et al. (2013) that revealed that gunshot injuries 
represented only $3 \%$ of hospitalized injured cases, this marked increase in the frequency of firearm injuries after revolution seemed to be sustained and not decreased even after 5 years of the revolution, this may be related to the smuggling of horrible amounts of all kinds of arms and weapons that were delivered to our community without any restrictions from the surrounding countries especially Libya and Sudan. Furthermore possession of different forms of weapons is one of the most established traditions in Upper Egypt society especially Assiut. After the $25^{\text {th }}$ revolution almost all houses in Assiut and the surrounding places have weapons, this together with the unstable security conditions pave the way for recovery of the phenomenon of revenge among families which already has its impeded roots in the study region. All these factors explained the marked increase in firearm injuries in the studied cases after the $25^{\text {th }}$ Revolution.

Egypt has the highest road traffic injuries fatality rate in the Eastern Mediterranean Region. Globally road traffic injuries are predicted to become the seventh leading cause of death by 2030 (Puvanachandra et al., 2012). In this study, road traffic accidents came after assault from others and represented $28 \%$ of injured hospitalized cases, this percentage was lower than that mentioned in a similar study in Assiut Trauma Unit $(31.1 \%)$ )(WHO, 2012b). Firearm injuries were almost equal to road traffic accidents as a cause of hospitalization. We assumed that January $25^{\text {th }}$ Revolution changed the pattern of trauma from accidental mode of road traffic accidents and falls to homicidal one in the form of assault from others and firearm injuries. Furthermore, road traffic accidents were the first cause of deaths among the hospitalized cases with more than $38 \%$ in this study as well as in many other studies (Solagberu et al., 2003 and Gururaj, 2005) followed by firearm injuries and Assault from others (32 and $20.1 \%$ respectively) as shown in table (5). Deaths from homicidal mode of trauma represented more than $55 \%$ of deaths which was much higher than any period before table (5).

\section{CONCLUSION}

Pattern of trauma in hospitalized patients changed dramatically after the January $25^{\text {th }}$ Revolution from the accidental mode of trauma (Road traffic accidents and falls) to Homicidal mode (Assaults from others and firearm injuries), this change in pattern to a great extent was related to the political and security instability which accompanied the years of revolution.

\section{Financial Support and Sponsorship None}

\section{Conflicts of Interest}

The authors declare that there are no conflicts of interest.

\section{REFERENCES}

Abdou, D.S.; and Zaazou Z. (2013): The Egyptian Revolution and Post Socio-economic Impact. Topics in Middle Eastern and African Economies Vol. 15, No. 1, May 2013. Available at SSRN: https://ssrn.com/abstract=2848704

Aldinger, C.; Noguera, J. and Reed, J. (2011): Why invest in violence prevention. Geneva, Switzerland and Newton, USA: Violence Prevention, Alliance and World Health Organization, found at.www.who.int/violenceprevention 
/publications/why_invest_in_violen ce.pdf

Barek, A.; Haque, S.M.T. (2013): Medicolegal aspects of hurt, injury, and wound. Anwer Khan Mod Med Coll J; 4 (2):37-41.

Bruce, J.C.; Schmollgruber, S.; Eales, Jasmin, G.; and Vanessa, D. (2003): Injury surveillance at a level 1 trauma centre in Johannesburg, South Africa. Health sa gesondheid; 8(3):3-12, found at https://www.ajol.info/index.php/hsa /article/view/10223

Gururaj, G. (2005): Background Papers: Burden of Disease. New Delhi: The National Commission on Macroeconomics and Health, Ministry of Health and Family Welfare; Injuries in India: A national perspective; pp. 32550.citeseerx.ist.psu.edu/viewdoc/do wnload?doi 10.1.1.461. 2995\&rep $=$ rep 1 .

Korkmaz, T.; Kahramansoy, N.; Erkol, Z.; Sarıçil, F.; and Kılıç, A. (2012): Evaluation of Medicolegal Case applied to Emergency service and the Judicial Reports. Haseki Tip Bülteni. 50(1) [in Turkey]

Mahran, D.G.; Farouk, O.A.; Qayed, M.; and Berraud, A.F. (2013): Hospitalized injuries and deaths in a trauma unit in Upper Egypt. Int $\mathbf{J}$ Crit Illn Inj Sci. 2013 Oct; 3(4):235-40. doi: 10.4103/22295151.124108.

Mahran, D.G.; Farouk, O.; Qayed, M.H.; and Berraud, A. (2016): Pattern and Trend of Injuries among Trauma Unit Attendants in Upper Egypt. Trauma Mon.; 21(2): 20967. [PMC free article] [PubMed]

Mann, C.V.; and Russell, R.C. (1991): Accident and emergency warfare injuries. In: Bailey and Love's short practice of surgery. 21st ed. London, UK: Hodder Arnold 1991-12-01 Nelson book services; 14-28.

Mant, A.K. (1984): Taylor's Principles and Practice of Medical Jurisprudence. Wounds and their interpretation. 13th ed. London: Churchill Livingstone. p. 214-248. ISBN-13: 978-0443014819

Murray, C.J.; and Lopez, A.D. (1997): Alternative projections of mortality and disability by cause 1990-2020: Global Burden of Disease Study. Lancet. 349(9064):1498-504. doi: 10.1016/S0140-6736(96)07492-2. [PubMed] [Cross Ref]

Ottaway, M. (2011): The Emerging Political Spectrum in Egypt. Carnegie Endowment for International Peace. Available at: http://www.carnegieendowment.or g/2011/10/10/emerging-political. .

Puvanachandra, P.; Hoe, C.; ElSayed, H.F.; Saad, R.; AlGasseer, N.; Bakr, M.; and Hyder, A.A. (2012): Road traffic injuries and data systems in Egypt: addressing the challenges. Traffic Inj Prev.; 13(Suppl 1):44-56.Cross Ref PubMed Google Scholar

Saad, S.; Salama, K.M.; and Moghazy, M. A. (2016): Incidence, topography, types of firearm injuries before and after the revolution of the 25th of January 2011: a hospital-based study Int Surg J. Aug; 3(3):1193-1198 http://www.ijsurgery.com pISSN 2349-3305 | eISSN 2349-2902

Saadat, S.; Mafi, M.; and Alhoseini, S. M. (2011): Population based estimates of non-fatal injuries in the capital of Iran. BMC public health, 
11(1):1. [PMC free article] [PubMed]

Solagberu, B.A.; Adekanye, A.O.; Ofoegbu, C.P.; Udoffa, U.S.; Abdur-Rahman, L.O.; and Taiwo, J.O. (2003): Epidemiology of trauma deaths. West Afr J Med.; 22:177-81. PMID: 14529233 [PubMed].

Tabish, S.A.; Shah, S.; Bhat, A.S.; Bhat, F.A.; Shoukat, H.; and Mir, M. (2004): Clinical profile and mortality pattern in patients of ballistic trauma. JIMSA; 13:247250

https://www.ncbi.nlm.nih.gov/pmc/ articles/PMC4369531/

World Health Organization (2012a): Injury surveillance: A tool for decision-making: Annual injury surveillance report, Egypt, 2009. World Health Organization. Regional Office for the Eastern Mediterranean, Arab Republic of Egypt and Ministry of Health. 2010. Available from: http://www. emro.who. int/dsaf/dsa1087.pdf

World Health Organization (2012b): Cairo Regional Office for the Eastern Mediterranean (Egypt). Eastern Mediterranean status report on road safety: Call for action. 2010. Available from: http://www.emro.who.int/cbi/pdf/w hd_2010_report.pdf. 
هل غيرت ثورة 25 يناير المصرية النمط الطبي الشرعي والإتجاه لإصابات المستثفيات في صعيد مصر؟

دعاء محمد عبد الرحمن الثهابي1 ـ مدحت عربي خليل صالح² ـ محمد صفوت شاهين33 ـ مصطفي محمود سيد

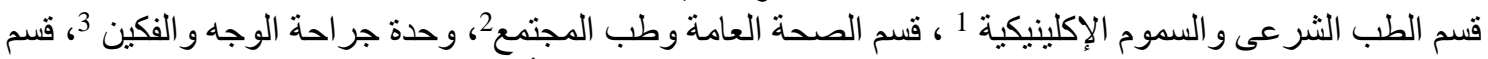

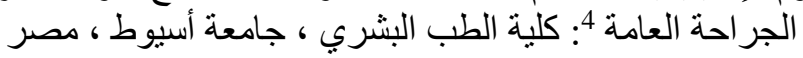

الإصابات هي حالة طبية لها آثار قانونية. ولقد رافقت الثورة المصرية في 25 يناير 2011 تغير التيرات واضحة في

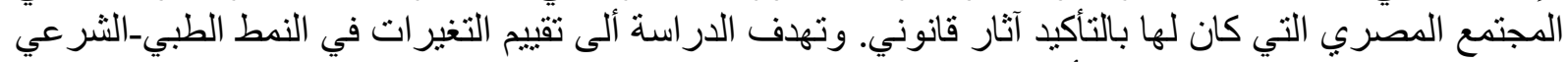

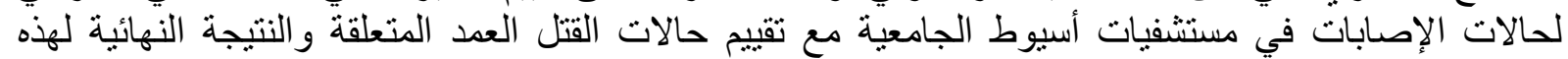

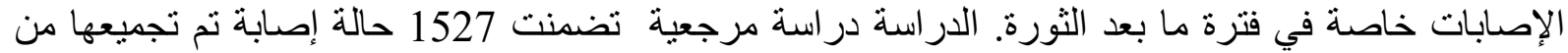
قاعدة بيانات وحدة الإصابات في مستشفى أسيوط الجامعي في الفترة ما بين يناير 2010 ودئة وديسمبر 2016.

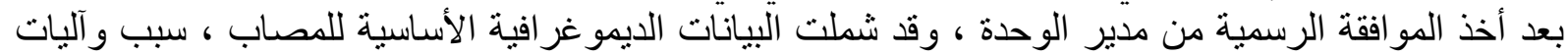

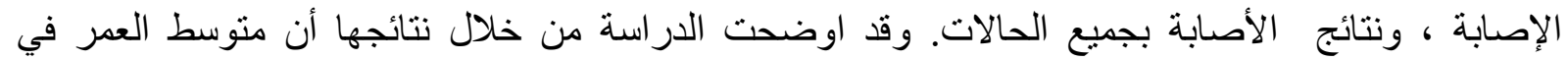

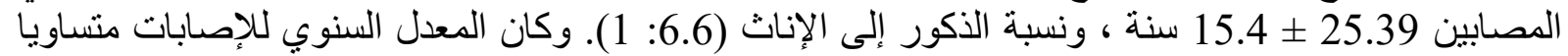

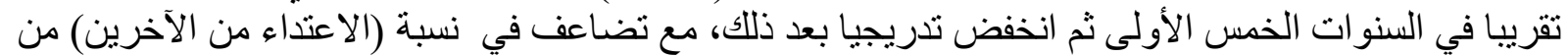

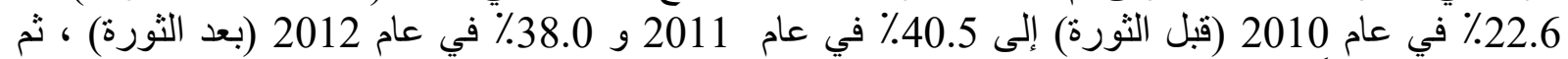

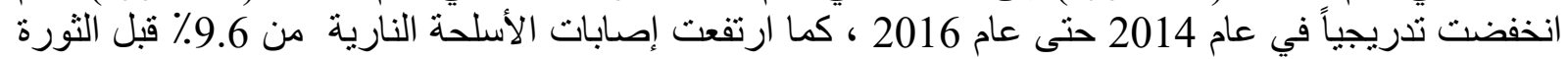

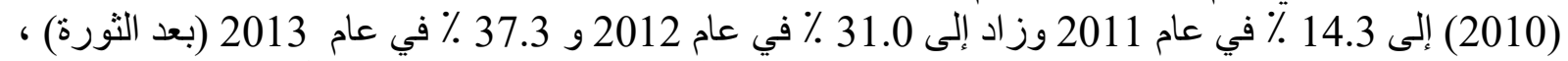

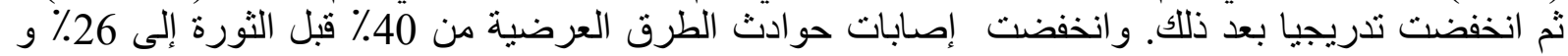

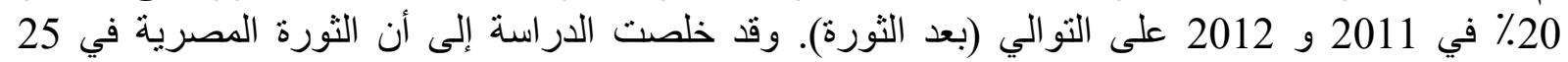

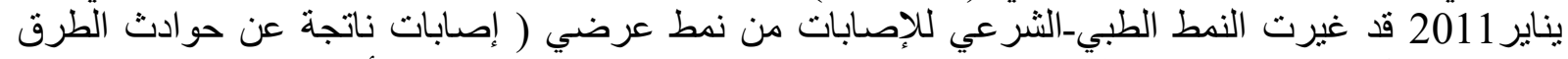

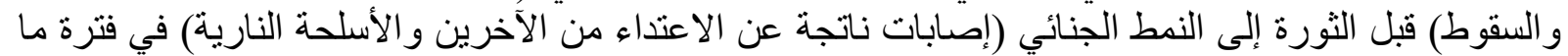
بعد الثورة. 